\title{
REDUCING THE DEVELOPMENT GAPS BETWEEN REGIONS IN POLAND WITH THE USE OF EUROPEAN UNION FUNDS
}

\author{
Adam CZUDEC (D)1, Ryszard KATA (D)2, Małgorzata WOSIEK (iD) ${ }^{3}$ \\ ${ }^{1}$ Department of Economic Policy, Faculty of Economics, University of Rzeszow, Rzeszow, Poland \\ ${ }^{2}$ Department of Financial Markets and Public Finance, Faculty of Economics, \\ University of Rzeszow, Rzeszow, Poland \\ ${ }^{3}$ Department of Microeconomics, Faculty of Economics, University of Rzeszow, Rzeszow, Poland
}

Received 04 July 2018; accepted 26 January 2019

\begin{abstract}
The paper evaluates the processes of regional income convergence in Poland. This new research approach involves an attempt to assess the process of convergence from the point of view of development gaps. Six key development gaps were considered in the region of Eastern Poland, which is a singular case, significantly different from other regions. A dynamic panel data model was applied to investigate the impact of EU funds on the progress made towards closing these development gaps. Among the analysed development gaps, only the structural gap was not reduced in the period 2004-2015. Studies have also revealed the different impact of structural funds on each category of development gaps (a positive impact on reducing the regional transport accessibility gap and the investment gap, but negative - on reducing the innovation gap). Research has suggested the need for a change in the structure of using EU funds in the period 2014-2020 to favour stronger support for entrepreneurship and the creation of new jobs. Greater stimulation of the economic structure of peripheral regions has been proposed as the prerequisite for the future reduction in the discrepancies between regions and for the intensification of convergence.
\end{abstract}

Keywords: development gaps, regional income convergence, Eastern Poland, EU funds, regional development, Cohesion Policy.

JEL Classification: O47, R11, R58.

\section{Introduction}

One of the priorities of the EU Cohesion Policy is to reduce development disparities between regions by increasing the competitiveness of the economy and improving the quality of life of the inhabitants of less developed regions. This problem gained renewed significance after the accession to the EU of countries from Central and Eastern Europe, which meant a large drop in GDP per capita on average for the EU, large inter-regional disparities between the "old"

\footnotetext{
*Corresponding author. E-mail: mwosiek@ur.edu.pl
} 
and "new" EU members, and which was also a result of the weakening effects of the cohesion policies at the turn of the twenty-first century (Puigcerver-Penalver, 2007). For those reasons, regions in Poland were largely benefiting from EU funds since 2004 (in all regions, GDP per capita did not exceed $75 \%$ of the EU-27 average). The constant growth of support in the form of EU funds is a distinctive feature in Poland's case. In 2004-2006, the annual average of this support amounted to about EUR 4.3 billion (in current prices) and in 2007-2013, it amounted to EUR 9.6 billion. For 2014-2020, it is expected to reach approximately EUR 11.8 billion on average per year (Szlachta, 2016).

Although all Polish regions are eligible for support from EU funds, there are large interregional differences regarding the level of economic development in Poland, which are particularly visible between the regions of Western or Central Poland and the regions of Eastern Poland (EP). The less developed EP regions cover $31.6 \%$ of Poland's territory and are inhabited by over 8 million people (21\% of the country's population). The main economic problem of these regions is their limited ability to improve the structure of the economy in response to changing macroeconomic conditions, which in turn makes these EP regions less attractive to investors (J. Misiąg, W. Misiąg, \& Tomalak, 2013; Nazarczuk, 2013; Gorzelak, 2014; Churski, 2004). The foremost social consequence of this shortcoming is migration, which has persisted for many years and which has led to a decreasing population in EP. Another important problem of the Eastern regions is also their low tendency to innovate (Lewandowska, 2016).

One of the instruments used in Poland under the Cohesion Policy to inhibit the increasing disparities between regions is the special Operational Programme "Development of Eastern Poland" (DEP OP), which was launched in 2007 and continues in the 2014-2020 time frame. The main priorities of this programme are the development of transport infrastructure, and support for entrepreneurship and innovative SMEs.

In this context, it seems important to find an answer to the question on the effects of the use of EU funds in Poland, measured by means of the dynamics and scale of reduction of development disparities between regions. In addition, it is important to assess the significance of the special programme for EP, which - integrated with other programmes ${ }^{1}$ - is assumed to contribute to boosting the processes of interregional convergence in Poland.

Against this background, the main goal of this research is to assess the importance of EU funds in supporting regional development in Poland, especially in reducing development gaps between the poorer EP regions and the rest of the country. We consider six indicators referring to the most important development gaps among EP regions. A dynamic panel data method (System Generalised Method of Moments) was applied to investigate income convergence across Polish regions and the impact of EU structural funds on the progress made towards closing these development gaps. We used data annual frequency over the years 2004-2015.

We assume that reducing development gaps will enable the acceleration of the income convergence process between the less developed EP regions and the rest. Although EU funds

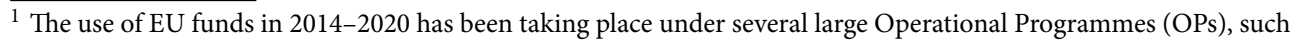
as: The Infrastructure and Environment OP; The Smart Growth OP; Knowledge Education Development; Regional Operational Programmes and Eastern Poland OP. Similar programmes were implemented in 2007-2013.
} 
do not have a direct impact on stimulating development, they can be used to a greater or lesser extent to promote activities leading to the reduction of development gaps and, thus, influence the process of regional income convergence. The assessment of the progress in eliminating development gaps as a consequence of the existing support of economically weaker regions from EU funds (2004-2013) can be important in determining the time frame for any further state aid deemed necessary to achieve the desired convergence.

We present our considerations in several sections. In the first part, a critical review of the results of previous studies on the regional convergence process was conducted and the need for new research focused on the diagnosis and evaluation of the reduction of development gaps was pointed out. The second section describes the research methods. In the third part, we analyse the level of EU funds and areas of support for the socio-economic cohesion of EP regions, with a particular focus on the DEP OP. The fourth section presents the results of the research regarding the reduction of key development gaps in the EP regions. In the following section, we analyse the impact of EU funds on development gaps and the process of regional income convergence. The paper concludes with the most important research findings.

\section{Theoretical framework}

The issues related to convergence processes are quite broadly addressed in the literature. Two main approaches can be distinguished:

1. The examination of convergence processes (beta-, sigma convergence) using interregional benchmarking;

2. The search for the major factors affecting the dynamics of regional convergence processes.

In the case of the former, most studies assess the dynamics of the convergence process among all regions (NUTS 2) in the EU. The authors indicate in their conclusions that the club convergence type is clearly visible in the EU, and that the differences between the regions grouped this way remain stable also in the long term (Fischer \& LeSage, 2015; Mikulić, Lovrincević, \& Galić-Nagyszombaty, 2013; Piętak, 2015).

The cognitive value of such research consists in demonstrating the dynamics of interregional convergence, but it is poorly aimed at diagnosing the sources of convergence, that is identifying the main factors that determine the dynamics of this process. Some studies attempt to determine the importance of the spatial distribution of regions in the EU in regard to the interregional convergence process, and relations with closest neighbours are found to be significant (Bal-Domańska, 2014). Attention is also drawn to the effects of the economic crisis in 2008, which disturbed the process of interregional convergence in the EU (Recher \& Kurnoga, 2017), as well as demographic changes, which involved a significant reduction in population in recent years (by $15 \%$ for Latvia and Lithuania; by $11 \%$ for Bulgaria and Romania). In this case, even minimal GDP growth brought about a significant increase of GDP per capita, especially in comparison with regions from developed countries, which are characterised by a high population growth rate (Luxembourg by $25 \%$; Ireland by $21.5 \%$ in 2000-2013) (Borowiec, 2015). 
Comparative research covering a very large number of regions can lead to excessively simplified reasoning, whereby most regions in Poland are regarded as specialising in agriculture, despite the fact that the share of agriculture in their GDP only ranges from $3 \%$ to $4 \%$ (Thiessen, van Oort, Diodato, \& Ruijs, 2013). This happens when, due to the large sample size, it becomes difficult to determine the real impact of many different factors influencing the studied phenomenon.

Some authors in the field of regional convergence in the EU focus on the evaluation of this process between regions in Western Europe and the regions of Central and Eastern Europe (CEE) (Moisescu, 2015; Piętak, 2015). At the Member State level, the convergence process in the newly acceded EU Member States was much more evident than in the "old" EU-15 in the first decade of the twenty-first century (Schadler, Mody, Abiad, \& Leigh, 2006; Čihák \& Fonteyne, 2009; Próchniak \& Witkowski, 2013). This was the result of a significantly lower GDP growth rate in the EU-15 regions than in the newly acceded EU Member States (Niebuhr \& Schlitte, 2009). If we look at the regions independently from groups of countries, however, we can see an increasing dispersion of income across EU regions. In most CEE countries, divergence took place (the richer the region, the higher the GDP growth) (Nazarczuk, 2013). This way, the interregional development gap within EU Member States, in particular the CEE countries, is widening, which means that there are processes of income polarisation present in these regions (Neumann, Budde, \& Ehlert, 2014).

The weakness of this type of studies is generally the absence of attempts to explain the causes of the widening disparities in development between regions of Western Europe and $\mathrm{CEE}$, in spite of the large transfers of funds from the EU budget to the latter.

This gap is filled by research whose goal is to identify the main factors that affect the dynamics of the process of reducing development disparities between regions. The main factors usually mentioned include:

1. The dynamics and characteristics of migration processes (Ozgen, Nijkamp, \& Poot, 2010);

2. The quality of human capital and the specifics of the labour market (Hurju, 2015; Próchniak \& Witkowski, 2013);

3. The complexity of economics and the structure of the economy (Mora, 2008; Mikulić et al., 2013; Firgo \& Huber, 2014);

4. The resources of the natural environment (Salvati, 2014);

5. The quality of the infrastructure present (Del Bo, Florio, \& Manzi, 2010);

6. The quality of life in rural areas (Spellerberg, Huschka, \& Habich, 2007);

7. Liberalisation of international trade and intensification of integration processes (Monfort \& Nicolini, 2000).

8. The role of institutions in the absorption of European funds (Ederveen, De Groot, \& Nahuis, 2006; Rodríguez-Pose \& Garcilazo, 2015);

9. The importance of geographic localisation and the proximity of regions (Ramajo, Marquez, Hewings, \& Salinas, 2008).

The results of such research make it possible to clarify the relationships between one of the factors affecting the growth rate of the economy and the dynamics of the interregional 
convergence process. A weakness is the almost exclusive focus on one factor while disregarding its connection with other determinants of economic growth, including the scale of support with regional policy instruments, in particular with EU funds.

This particular issue seems especially important, because every EU country allocates considerable funds for regional support. It is, therefore, legitimate to examine how these measures accelerate the processes of regional convergence. Researchers have shown that between 1994-2006, in Germany, there was a reduction in disparities between the less developed regions (mainly in the eastern part of the country) and regions with a high level of economic development. This was possible with the use of special subsidies for the less developed regions (Alecke, Mitze, \& Untiedt, 2013). Research on the correlations between the volume of support for regions in Poland from EU funds and the rate of economic growth has been conducted by Misiąg et al. (2013). Additionally, Lewandowska, Stopa, and Humenny (2015) have attempted an analysis of the impact of EU structural funds on the development of smalland medium-sized enterprises in EP.

The research by Misiąg et al. (2013) shows that:

- EU funds were not a factor that significantly affected the growth rate of individual regions in 2004-2011;

- The significant preference granted since 2007 in the distribution of EU funds to EP regions did not provide the expected acceleration of economic growth in these regions and did not induce their "catching up" with the rest of the country.

In this context, it is important to determine the reasons for such a state of affairs and to use this information to establish ways to improve the use of EU funds in EP regions. In our research, we assumed that in order to benefit more from the use of EU funds vis-à-vis the dynamics of the convergence process, it is necessary to diagnose correctly and subsequently eliminate effectively the essential development gaps that impact on these interregional disparities.

In this study, a development gap is understood as a disparity in the level of social or economic resources in the region, during the specified time period, as compared to the regions with the highest level of the given resource or as compared to the average levels of the resource in a country. Our attention will focus on the qualities of resources (endogenous resources) that are essential for economic development. Such an approach to development gaps has not been adopted previously in the context of regional convergence. ${ }^{2}$ In this article, the difference in the level of development of a given resource will be compared to the average values applicable for Poland.

The analysis of reducing the differences in socio-economic development should, therefore, be based on the analysis of development gaps between poorer and richer regions. This is about determining whether and how quickly the development gaps decrease, which is a necessary condition for regional convergence. Another important issue is the evaluation of

\footnotetext{
2 The concept of the development gap was first identified in the sphere of business management, in the context of the competitive advantages of a company (technological gap, innovation gap etc.) (Bełz, Malinowski, \& Olejczyk, 2013). In terms of the economic development of regions or countries, the notion of a technological gap determines the differences in technological development among countries/regions (Grabicz, 2012; Kubielas, 2009). The concept of the development gap also refers to the overall difference in socio-economic development among countries (Tusińska, 2012; Mucha-Leszko, 2013).
} 
the effectiveness and efficiency (relationship of expenses to effects) of financial support from EU funds, targeted at reducing development gaps.

As is clear from the literature review, a large number of studies on interregional convergence in the EU provide comparative analyses of all (or most) regions in the EU. Such an approach can lead to excessive simplifications in reasoning, as the process of economic growth in various EU Member States is affected by entirely different economic factors (for example, the current level of economic growth, the structure of the economy, the ability to respond quickly to changes in the macro-environment) and social factors (demographic processes, the availability of various infrastructure components).

Our research focuses on regions in Poland that function in similar economic conditions and are under the influence of similar economic policy instruments (for example, a tax system, labour market regulations, support for innovation), which gives rise to the assumption that the process of convergence is affected by similar groups of economic and social factors. This, in turn, is the basic prerequisite for a proper diagnosis of the major development gaps that have a significant impact on the dynamics of interregional convergence.

The new approach adopted in our research also involves an attempt to demonstrate the relationship (or the lack thereof) between the use of EU funds by regions in Poland and the elimination of development gaps. It seems important to note that the first specialised EU programme aimed at promoting the five least developed EP regions was introduced in 2007. Therefore, it is justified in cognitive terms to determine the importance of such a programme - in conjunction with all other EU programmes - in boosting the convergence process in Poland.

\section{Methods and data}

The research tasks used to achieve the main research objective were:

- to identify the most important development gaps in EP regions;

- to assess progress in reducing development gaps in EP regions in the period 20042015;

- to assess the scale of regional development support from EU structural funds for EP regions and analyse the objectives of this support in terms of reducing development gaps.

This paper was written under the assumption that the following hypotheses would be verified:

1. The implementation of EU programmes has had a positive impact on reducing the development gaps between EP regions and the rest.

2. In the period 2004-2015, the level of reduction in development gaps between EP regions and the rest was insufficient to initiate the process of income convergence.

In recent years, both economic theories (new theories of growth, new economic geography) and regional policies have strongly emphasised the importance of endogenous factors of regional development, which should boost economic development both at local and regional levels (Pardo Garcia, 2005; Próchniak, 2009; Nazarczuk, 2013). Taking into consideration the main area of use of EU funds, and in line with various research findings dealing with prob- 
lems of interregional disparities (Ekspertyzy do Strategii Rozwoju Polski Wschodniej do 2020 roku, 2007; Gorynia, Nowak, \& Wolniak, 2007, Czudec, 2009; Jabłoński, 2012; Nazarczuk, 2013), six major development gaps in EP regions were considered for analysis: the technology gap, the innovation gap, the human capital gap, the regional transport accessibility gap, the investment gap and the structural gap. Variables representing the level of development of a given feature, were adopted for each gap (Table 1).

A development gap was recognised as a disparity in the level of development of an economic resource in the region in comparison with the average level of the given resource in the country:

$$
D G_{i, j, t}=\frac{x_{i, j, t}}{x_{i, n, t}},
$$

where: $D G_{i}$ - the development gap for the $i$-th economic resource; $x_{i}$ - the level of development of the $i$-th economic resource $(i=1,2, \ldots 6)$; indices $j, n, t$ mean: $j$ - region, $n$ - national average, $t$ - time.

Table 1. Development gaps in EP regions (source: own study)

\begin{tabular}{|l|l|c|l|}
\hline \multicolumn{2}{|c|}{ Development gaps } & Variable & \multicolumn{1}{c|}{ Statistical indicators } \\
\hline$D G_{1}$ & Technology & $x_{1}$ & $\begin{array}{l}\text { Intramural R\&D expenditure per capita } \\
\text { (in constant prices) }\end{array}$ \\
\hline$D G_{2}$ & Innovation & $x_{2}$ & $\begin{array}{l}\text { Patents granted by the Polish Patent Office } \\
\text { per 1 million population }\end{array}$ \\
\hline$D G_{3}$ & Human capital & $x_{3}$ & $\begin{array}{l}\text { Percentage of population aged 15 or over } \\
\text { with tertiary education }\end{array}$ \\
\hline$D G_{4}$ & Transport accessibility & $x_{4}$ & Expressways and motorways per 1,000 $\mathrm{km}^{2}(\mathrm{in} \mathrm{km})$ \\
\hline$D G_{5}$ & Investment & $x_{5}$ & $\begin{array}{l}\text { Investment outlays in enterprises per capita } \\
\text { (in constant prices) }\end{array}$ \\
\hline$D G_{6}$ & Structural & $x_{6}$ & Employment rate in industry and services \\
\hline
\end{tabular}

The development gap can be seen as a disparity in the level of development of a particular social or economic resource in the region in comparison with the region with the highest level of the given resource or in comparison with the average level of that resource in the country. In our research, we adopted the position that a comparison with the national average is more appropriate than a comparison with the leader. The problem of less developed regions is encapsulated in the fact that they are equipped with specific economic and social resources (important for the boosting of economic growth) at a significantly lower level in comparison not only with the leader, but with other regions in the country. The fact that less developed regions lag behind the national average is the actual development gap, that is a barrier in the process of income convergence.

Analysing the development level of factors by reference to the national average enables the comparison of the value of the gap indicator for the $i$-th feature in region $j$ over various periods, and the assessment of progress in reducing the development gap in said regions (for which $\left.D G_{i}<1\right)$ :

$$
\Delta D G_{i, j}=D G_{i, t 1}-D G_{i, t 0}
$$


If $\Delta D G_{i, j}>0$, there is progress in closing the development gap for the $i$-th feature in region $j$ relative to the national average between year $t_{0}$ and $t_{1}$. The higher the value of parameter $\Delta D G_{i, j}$, the greater the achievements of the $j$-th region in bridging the development gap for the $i$-th feature in relation to the average values of the country. If $\Delta D G_{i, j}<0$, the relative development gap for feature $i$ of the $j$-th region in relation to the national average becomes larger.

At the next stage of the research, the interregional (conditional) $\beta$-convergence in Poland for 2004-2015 was verified. In empirical growth literature, the $\beta$-convergence hypothesis is usually tested based on the neoclassical growth model (Barro \& Sala-i-Martin, 1991, 1992; Mankiw, Romer, \& Weil, 1992). Furthermore, studies largely employ panel data methods to investigate convergence across regions, as these methods allow for region-specific intercepts. Preference has been given to the System Generalized Method of Moments (sGMM), as it increases the efficiency of estimation (Badinger, Müller, \& Tondl, 2004). Consistent with these findings, and in order to verify the interregional $\beta$-convergence in Poland, we employ the following equation, which is based on the Mankiw, Romer and Weil (1992) model:

$$
\ln \left(y_{j, t}\right)=\alpha_{0}+(\gamma+1) \ln \left(y_{j, t-1}\right)+\theta^{T} X_{j, t}+\left(\alpha_{j}+\mu_{t}+\varepsilon_{j, t}\right),
$$

where: $y_{j, t}$-GDP per capita (in constant prices) of region $j$ at time $t ; X_{j, t}$ - vector of explanatory variables; $\alpha_{0}, \gamma, \theta$ - regression coefficients, $\alpha_{j}$ - fixed-region effects, $\mu_{t}$ - fixed time effects, $\varepsilon_{j, t}$ - error.

As explanatory variables we considered - according to the MRW model - the variables used in the basic version of the conditional $\beta$-convergence equation: $\operatorname{In} v_{j}, t-1$ - capital expenditure per employee (in constant prices from the year 2000), $p o p_{j, t}$ - population (at working age) growth rate (plus $g+\delta^{3}$ ). The parameters of regression equation were estimated using the sGMM method (investment was treated as an endogenous variable).

In order to capture the relationship between:

- the level and growth rate of GDP per capita and the progress in reducing development gaps $\left(\Delta D G_{i}\right)$;

- the volume of the structural funds allocated in the regions and the progress made towards closing the development gap $\left(\Delta D G_{i}\right)$;

- a correlation analysis (using the Pearson correlation coefficient) was conducted.

In order to verify the cause-and-effect links between the EU structural funds that flowed to the regions and the change in regional disparities in Polish regions in the period 20042015 estimates of the dynamic panel model were conducted. The following regression equation was employed (4):

$$
D G_{i j, t}=\alpha_{0}+\alpha_{1} D G_{i, j, t-1}+\alpha_{2} \ln f_{j, t-1}+\alpha_{3} Z_{j, t-1}+\left(\alpha_{j}+\mu_{t}+\varepsilon_{j, t}\right),
$$

where: $D G_{i, j, t}$ - the development gap of the $i$-th feature in the region $j$ in year $t ; f_{j, t-1}$ - the EU structural funds per capita (constant prices) in the $j$-region in $t-1$ time period; $Z_{j, t-1}-$ set of control variables in the $j$-region in $t$ - 1 time period; $\alpha_{0}, \ldots, \alpha_{3}$ - regression coefficients, $\alpha_{j}$ - fixed-region effects, $\mu_{t}$ - fixed time effects, - error term of the specification.

\footnotetext{
${ }^{3}$ The coefficient $\mathrm{g}+\delta=0.05$ is a standard value used in most studies on convergence (its value reflects the rate of depreciation of capital and the rate of technical progress).
} 
The regression equation includes a time lag of the variable for the volume of the structural funds in the regions in order to reflect the fact that their impact is revealed with some delay. The set of control variable $Z_{j, t-1}$ includes additional determinants of development gap changes, such as:

- $\ln n f_{j, t-1}$ - logarithm of national structural expenditure ${ }^{4}$ per capita (constant prices), verifying the impact of national funds aimed at reducing development gaps in $j$-region in $t-1$ time period;

- In GDP $P_{j, t-1}$ - logarithm of GDP per capita in j-region in $t$-1 time period (constant prices), as the most representative and comprehensive gap category (final and summary result of various development gaps). Controlling GDP per capita stems from the theoretical findings of New Economic Geography, which forms the basis for studies on convergence and income polarisation in the inter- and intraregional contexts. The key premise of the theory is the assumption that there is a need for a comprehensive analysis of all factors determining regional development (Krugman, 1998; Camagni, 1995). The greatest development effects are achieved when there is coherence in reducing the development gap in various dimensions.

The sGMM estimators were chosen as an estimation method. There are several reasons for choosing this method:

- the process of bridging a development gap is dynamic - the current realisations of the $D G_{\mathrm{i}}$ variable may be influenced by past ones. Thus, the standard estimation methods such as OLS or fixed-effects models for panel data - are not appropriate, as they do not account for the dynamic structure of the estimated equation;

- the bridging of a development gap depends on various factors, not just on EU structural funds - the regression equation should include the appropriate control variables;

- some development gap determinants (e.g. institutional conditions) are difficult to capture, as the proxy for these determinants may serve the lagged dependent variable. On the one hand, the inclusion of the lagged dependent variable minimises the risk of omitted-variable bias, but on the other it can cause endogenity in this variable.

For this reason, we use the sGMM method, which in addition is designed for situations with a relatively short time series and the presence of not strictly exogenous variables (Roodman, 2009, p. 159). The problem of endogenity is reduced by instrumenting the explanatory variable (as instruments use lagged values of that variable and the lagged first-differenced variable). In order to assess the consistency of the sGMM estimators, the AR2 test for autocorrelation, the Hansen-Sargan test for over-identifying restrictions and the differencein-Sargan/Hansen test for the validity of instrument subsets were conducted and reported.

We estimate separate time-series regression equations for individual gap categories. In our study, we use data at annual frequency, so that the number of time periods $(T=12)$ available is as large as possible. We assumed structural funds as an exogenous variable: a) all Polish regions were eligible for support from the Structural Funds since 2004; b) the correlation analysis did not indicate a correlation between the level of the development gaps and the criteria for the allocation of funds (per capita) in the regions (the absolute values of the Pearson correlation coefficients did not exceed 0.06 and were statistically insignificant).

\footnotetext{
${ }^{4}$ Structural expenditure covers all public expenditure on development tasks that may be co-financed by the EU structural funds and the Cohesion Fund (Chrzanowski, 2015).
} 
The figures used in our research were retrieved from the Central Statistical Office dataset (CSO; Local Data Bank) and the Ministry of Infrastructure and Development, and refer to the period 2004-2015. This time frame was selected because of Poland's 2004 membership status in the EU and its newly gained access to structural funds for regional development, and the availability of data on the regional allocation of EU Structural Funds. The study period seems to be long enough to allow the observation and evaluation of changes in the economy of the regions in terms of bridging development gaps. The authors do realise, however, that for a comprehensive evaluation of that process, a longer period of time is required (as regards the use of EU funds by less developed regions).

\section{EU funds support for the socio-economic cohesion of regions in Poland}

Support to less developed regions in Poland in the form of public resources has a relatively short history, dating to 2004. In the first years of Poland's membership in the EU, relatively more EU funds were directed to economically stronger regions, which has not promoted the reduction of interregional disparities (Churski, 2008). Among the operational programmes co-financed by EU structural funds, in the context of the income convergence of regions in Poland, particular attention should be paid to the Development of Eastern Poland Programme (OP DEP). The objectives of this programme were aimed at reducing the most essential development gaps typical of EP regions. Nevertheless, the target of reducing regional disparities in the context of development gaps should also be assigned to other EU structural funds that were allocated to poorer regions under other operational programmes.

In the ranking of regions according to volume of EU expenditure (per capita) incurred in 2004-2013, the first place is occupied jointly by the following regions: Warmińsko-Mazurskie and Podkarpackie (Figure 1). The other EP regions ranked near the national average. This may be proof that the OP DEP did not provide enough financial assistance to enable more significant development of EP regions. Conversely, it may indicate the relatively low effectiveness of EP regions in competing for development support under those operational programmes, whose funds were allocated at the national level.

When comparing the level of structural expenditure per capita financed from EU funds to the national average, a significant increase was observed in EP regions in 2013 (107\%), in relation to $2004(91 \%)^{5}$. The increase in the funding stream allocated to EP regions (both under EU structural funds and national structural expenditure) has been particularly visible since $2009^{6}$ (Misiąg et al., 2013; Chrzanowski, 2015), which confirms that the OP DEP contributed to a relatively larger allocation of EU funds in EP regions. Nevertheless, a positive correlation coefficient between the global value of EU structural funds and the level of GDP per capita in $2004(\mathrm{r}=0.772 ; \mathrm{p}=0.00)$ shows that more developed regions received more support from EU funds. This is not the case when the value of EU funds is calculated in relation to the number of inhabitants (insignificant correlation, $r=-0.169 ; \mathrm{p}=0.531)^{7}$. Overall, structural

\footnotetext{
5 The ratio of national structural funds per capita in EP regions to the national average increased from $68 \%$ in 2004 and $90 \%$ in 2005-2008 to $97 \%$ in 2009-2013. Own calculations based on data from The Ministry of Infrastructure and Development (Chrzanowski, 2015, pp. 127-131).

${ }^{6}$ It refers to $\mathrm{N}+2$ rule, according to which payments can be called up two years after they have been allocated.

7 Own calculations based on data from CSO and from The Ministry of Infrastructure and Development (Chrzanowski, 2015, pp. 127-131).
} 


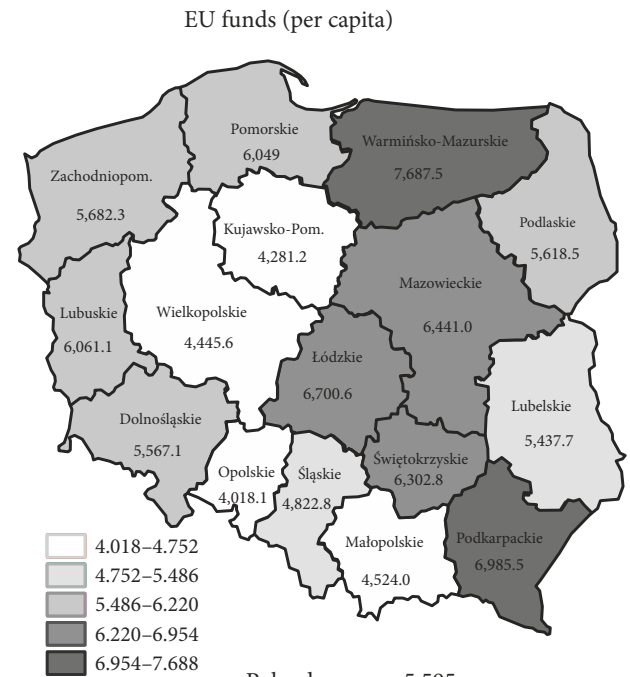

Poland average: 5,595

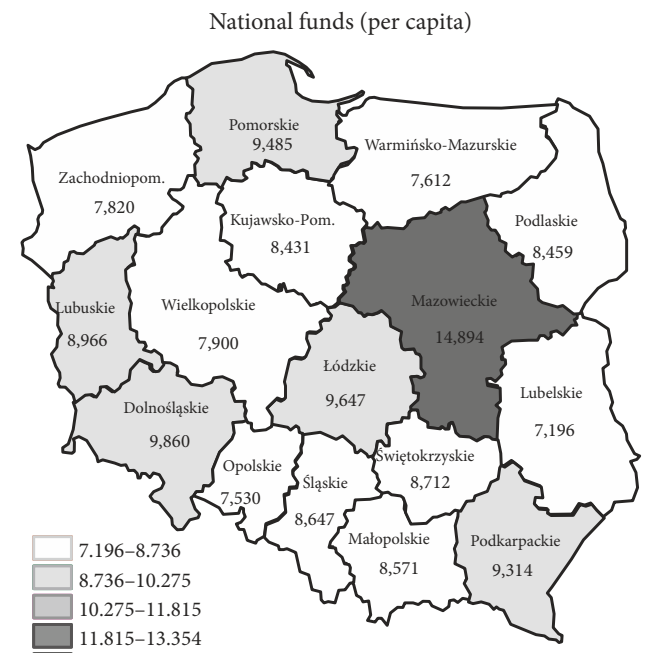

Poland average: 9,515

Figure 1. EU structural funds and national structural expenditure (per capita, PLN) in Polish regions in 2004-2013 (source: own calculations based on data from The Ministry of Infrastructure and Development (Chrzanowski, 2015, pp. 127-131; Program Polska Wschodnia 2014-2020, 2015)

funds were allocated for the development of basic technical infrastructure, the development of human capital and for direct support of research and technological development and innovation (European Funds Portal, n.d.).

Funds under the OP DEP in 2007-2013 were used to implement projects worth EUR 2.4 billion, financed by the European Regional Development Fund and the national budget (European Funds Portal, n.d.). Public funds were allocated largely to economic and social areas that correspond to the aforementioned development gaps in EP regions. ${ }^{8}$ In this sense, these funds should lead to a reduction in the disparities between EP regions and the rest of the country in terms of the development level of the factors constituting development gaps.

The programme aimed at supporting regional convergence in EP carries on in the 20142020 time frame. Under the Eastern Poland OP (EP OP), EUR 2.1 billion (excluding national contributions) will be allocated, which is similar to the previous contribution (European Funds Portal, n.d.). The funds of the EP OP support several areas, leading to greater competitiveness and innovation in the regions.

The correlation coefficient between the GDP per capita growth rate and EU expenditure (per capita) in Polish regions in 2004-2015 was negative $(r=-0.397 ; p=0.00)^{9}$, which is in line with the conclusions presented by Misiąg et al. (2013). The absence of a positive correlation between the volume of financial assistance from the EU budget and economic growth rate in the regions is a phenomenon that requires analysis aimed at explaining the reasons

\footnotetext{
8 The priority axis of OP DEP: Modern Economy, Transport Infrastructure, Regional Growth Centres, Information Society Infrastructure, Sustainable Tourism (European Funds Portal, n.d.).

${ }^{9}$ Own calculations based on data from CSO and from The Ministry of Infrastructure and Development (Chrzanowski, 2015, pp. 127-131).
} 
behind the low efficiency of the use of EU assistance. The authors assume in this research that development gaps are the main obstacle to the acceleration of economic growth in the less developed regions. Regional convergence is dependent on the pace and scale of reducing these gaps. In the case of slow dynamics in the reduction of development gaps, pro-growth incentives can be so small that will make it impossible to reduce the development gap between the poorer regions of the country and the rest.

\section{Development gaps in Eastern Poland}

In the period 2004-2015, there has been significant progress towards reducing most of the considered development gaps in EP regions (Table 2):

- in 2004-2015, R\&D expenditure per capita in EP regions increased on average by $18.8 \%$, whereas the corresponding average national increase was lower (13.3\%). Despite the dynamic growth of $\mathrm{R} \& \mathrm{D}$ expenditure in EP regions, in 2015, its level (56 EUR per capita) was still lower than the national average (102 EUR), except for Podkarpackie (106 EUR). The gap in this respect $\left(D G_{1}\right)$ decreased quite noticeably (by $0.26)$; however, it still exists and is significant;

- the number of patents granted by the UPRP (per capita) in all EP regions grew faster (20.4\%) than the national average (13.2\%) and, as a result, the innovation gap was also significantly reduced (by 0.26). Nevertheless, for this factor of development as well, the gap $\left(D G_{2}\right)$ between EP regions and the rest of the country remained very high still;

- in comparison with previously considered factors, the gap in the quality of human capital $\left(D G_{3}\right)$ between EP regions and the rest of the country, was not as significant both in 2004 and in 2015 (0.90). The group of Eastern regions, however, is not homogeneous. In particular, Świętokrzyskie and Warminsko-Mazurskie are characterised by an increasing human capital gap, while in Podkarpackie we observed a reduction of the development gap in the case of this resource. As a result, the gap $\left(D G_{3}\right)$ between Eastern Poland and more developed regions did not change significantly between 2004 and 2015;

- there were positive changes in the length of expressways and motorways $\left(D G_{4}\right)$. Progress in this respect was visible across the country, but in EP regions growth was much higher. In 2004, the saturation of these types of roads in EP was $12 \%$ compared to the national average, and 3.3\% compared to the most developed south-west region. In 2015, however, the saturation of expressways and motorways in EP reached $46 \%$ of the national average and $18.1 \%$ of the value for the most developed region. In this case, the gap between Eastern and more developed regions of the country decreased; however, it still exists and is significant;

- the average annual growth rate of capital expenditure per capita in all EP regions $(9.1 \%)$ was higher than the national average $(8.9 \%)$. Therefore, in this case as well, a reduction in the development gap $\left(D G_{5}\right)$ was observed. As can be seen, however, the positive changes did not enable the bridging of this gap, which is still very "wide". 
Table 2. Development gaps in 2004-2015 in Eastern Poland regions (source: own calculations based on CSO data)

\begin{tabular}{|c|c|c|c|c|c|c|c|c|c|}
\hline \multirow{2}{*}{ Region } & \multicolumn{2}{|c|}{$D G_{1}$} & \multirow{2}{*}{$\Delta D G_{1}$} & \multicolumn{2}{|c|}{$D G_{2}$} & \multirow{2}{*}{$\Delta D G_{2}$} & \multicolumn{2}{|c|}{$D G_{3}$} & \multirow{2}{*}{$\Delta D G_{3}$} \\
\hline & 2004 & 2015 & & 2004 & 2015 & & 2004 & 2015 & \\
\hline EP average & 0.36 & 0.62 & 0.26 & 0.43 & 0.59 & 0.26 & 0.90 & 0.90 & 0.00 \\
\hline Lubelskie & 0.57 & 0.73 & 0.16 & 0.85 & 1.40 & 0.54 & 0.97 & 0.96 & -0.01 \\
\hline Podkarpackie & 0.37 & 0.91 & 0.54 & 0.37 & 0.52 & 0.14 & 0.79 & 0.88 & 0.09 \\
\hline Podlaskie & 0.32 & 0.54 & 0.22 & 0.24 & 0.46 & 0.21 & 0.93 & 0.97 & 0.04 \\
\hline Świętokrzyskie & 0.10 & 0.44 & 0.34 & 0.34 & 0.41 & 0.06 & 0.98 & 0.87 & -0.11 \\
\hline Warmińsko-Mazurskie & 0.29 & 0.23 & -0.06 & 0.10 & 0.34 & 0.24 & 0.84 & 0.80 & -0.04 \\
\hline Other regions (average) & 1.18 & 1.10 & -0.07 & 1.16 & 1.08 & -0.07 & 1.03 & 1.02 & -0.01 \\
\hline Leader & 3.26 & 2.77 & -0.49 & 2.30 & 1.50 & -0.80 & 1.40 & 1.38 & -0.02 \\
\hline \multirow{2}{*}{ Region } & \multicolumn{2}{|c|}{$D G_{4}$} & \multirow{2}{*}{$\Delta D G_{4}$} & \multicolumn{2}{|c|}{$D G_{5}$} & $\Delta D$ & \multicolumn{2}{|c|}{$D G_{6}$} & \multirow{2}{*}{$\Delta D G_{6}$} \\
\hline & 2004 & 2015 & & 2004 & 2015 & $\Delta D v_{5}$ & 2004 & 2015 & \\
\hline EP average & 0.12 & 0.46 & 0.34 & 0.54 & 0.57 & 0.03 & 0.83 & 0.78 & -0.05 \\
\hline Lubelskie & 0.07 & 0.32 & 0.26 & 0.44 & 0.48 & 0.04 & 0.79 & 0.76 & -0.03 \\
\hline Podkarpackie & 0.00 & 0.71 & 0.71 & 0.61 & 0.63 & 0.02 & 0.87 & 0.81 & -0.06 \\
\hline Podlaskie & 0.00 & 0.23 & 0.23 & 0.59 & 0.62 & 0.03 & 0.80 & 0.76 & -0.05 \\
\hline Świętokrzyskie & 0.81 & 0.50 & -0.31 & 0.53 & 0.51 & -0.01 & 0.84 & 0.80 & -0.04 \\
\hline Warmińsko-Mazurskie & 0.04 & 0.60 & 0.55 & 0.58 & 0.64 & 0.06 & 0.83 & 0.78 & -0.05 \\
\hline Other regions (average) & 1.41 & 1.25 & -0.16 & 1.13 & 1.12 & -0.01 & 1.05 & 1.06 & 0.01 \\
\hline Leader & 3.73 & 2.55 & - & 1.89 & 1.66 & -0.23 & 1.24 & 1.27 & 0.03 \\
\hline
\end{tabular}

Among all development gaps, the structural gap $\left(D G_{6}\right)$ is the only one that was not reduced in the period in question but which, on the contrary, increased slightly. In the case of EP regions, the share of people employed in the industry and services sectors amounted to almost $35.1 \%$ in 2004 compared to $42.4 \%$ on average for the country. In 2015 , this indicator amounted to $39.5 \%$ in EP regions, whereas the national average was $50.5 \%$. Structural changes in the economy of EP regions were positive and reflected similar changes taking place across the country during this period. Positive changes in less developed regions, however, were slower than in other regions of the country.

\section{Reducing development gaps and income convergence in Polish regions}

Although in 2004-2015 most of the considered development gaps in Eastern Poland were reduced, the total GDP per capita growth rate in EP regions (43.9\%) did not exceed the national average (50.8\%) - Table 3. The correlation coefficient between GDP per capita in 2004 and GDP per capita growth rate for 2004-2015, amounting to $0.506(\mathrm{p}=0.045)$, proves that regions with a higher initial GDP per capita (in 2004) presented a higher rate of change of this measure. This rationale indicates an advantage of divergence processes over convergence ones in Polish regions. 
Table 3. The growth rate of GDP per capita in 2004-2015 (constant prices, $2000=100$ ) (source: own calculations based on CSO data)

\begin{tabular}{|l|c|c|}
\hline \multicolumn{1}{|c|}{ Specification } & The average annual growth rate & Total growth \\
\hline Poland & $\mathbf{4 . 3 4}$ & $\mathbf{5 0 . 8}$ \\
\hline EP (average) & $\mathbf{3 . 7 3}$ & $\mathbf{4 3 . 9}$ \\
Lubelskie & 3.84 & 46.0 \\
Podkarpackie & 3.85 & 47.1 \\
Podlaskie & 3.80 & 45.4 \\
Świętokrzyskie & 3.39 & 37.0 \\
Warmińsko-Mazurskie & 3.59 & 41.3 \\
\hline Other regions: & & \\
- average & $\mathbf{4 . 4 5}$ & $\mathbf{5 1 . 9}$ \\
- maximum & 5.18 & 66.2 \\
\hline
\end{tabular}

The estimation results (Table 4) confirm that in 2004-2015 Polish regions did not develop according to the neoclassical convergence hypothesis. Although estimate sGMM(1) suggests that regions with lower GDP per capita developed with higher rates of economic growth, these results are sensitive to inclusion of other control variables - estimation $\operatorname{sGMM}(2)$, $\operatorname{sGMM}(3)$. Adding variables representing capital expenditure (Inv) and population growth rate ( $p o p)$ alters significantly the results. The value of the $\gamma$ parameter is positive, which is a premise to the conclusion that divergence processes prevailed over convergence ones in Polish regions This result is statistically significant and the SGMM estimator seems to be

Table 4. Income convergence in Polish regions 2004-2015 (source: own calculations)

\begin{tabular}{|c|c|c|c|c|c|c|c|c|}
\hline \multirow{2}{*}{\multicolumn{2}{|c|}{ Estimation }} & \multicolumn{3}{|c|}{ Absolute convergence } & \multicolumn{4}{|c|}{ Conditional $\beta$-convergence } \\
\hline & & OLS & LSDV & sGMM (1) & OLS & LSDV & sGMM (2) & sGMM (3) \\
\hline $\mathrm{GDPpc}_{t-1}$ & $(1+\gamma)$ & $\begin{array}{c}1,012^{\star * *} \\
(0.003)\end{array}$ & $\begin{array}{c}0.722^{\star * \star} \\
(0.066)\end{array}$ & $\begin{array}{l}0.984^{\star * *} \\
(0.0276)\end{array}$ & $\begin{array}{c}1.010^{\star * *} \\
(0.014)\end{array}$ & $\begin{array}{c}0.706^{* * *} \\
(0.025)\end{array}$ & $\begin{array}{c}1.0116^{\star * *} \\
(0.0097)\end{array}$ & $\begin{array}{c}1.0156^{\star * *} \\
(0.017)\end{array}$ \\
\hline $\operatorname{Inv}_{t-1}$ & $\alpha_{1}$ & - & - & - & $\begin{array}{c}0.003 \\
(0.006)\end{array}$ & $\begin{array}{l}-0.017 \\
(0.017)\end{array}$ & $\begin{array}{l}-0.001 \\
(0.009)\end{array}$ & $\begin{array}{l}-0.001 \\
(0.013)\end{array}$ \\
\hline $\operatorname{pop}_{t}$ & $\alpha_{2}$ & - & - & - & $\begin{array}{c}0.009 \\
(0.007)\end{array}$ & $\begin{array}{c}0.036^{* * *} \\
(0.011)\end{array}$ & $\begin{array}{c}0.009 \\
(0.014)\end{array}$ & $\begin{array}{c}0.011 \\
(0.014)\end{array}$ \\
\hline \multicolumn{2}{|l|}{$\operatorname{AR}(2)$} & - & - & 0.634 & - & - & 0.520 & 0.520 \\
\hline \multicolumn{2}{|c|}{ Hansen/Sargan } & - & - & 0.831 & - & - & 0.262 & 0.162 \\
\hline \multicolumn{2}{|c|}{ diff.-in-Sargan/Hansen } & - & - & 1.000 & - & - & 0.489 & 0.009 \\
\hline \multicolumn{2}{|c|}{ No. of instruments } & - & - & 24 & - & - & 87 & 37 \\
\hline \multicolumn{2}{|c|}{ No. of observations } & - & - & 192 & - & - & 192 & 192 \\
\hline \multicolumn{2}{|c|}{ Instruments collapsed } & - & - & Yes & - & - & No & Yes \\
\hline \multicolumn{2}{|l|}{$\mathrm{R}^{2}$} & 0.999 & 0.988 & - & 0.989 & 0.988 & - & - \\
\hline
\end{tabular}

Note: statistical significance: ${ }^{*} \mathrm{p}<0.10,{ }^{* *} \mathrm{p}<0.05,{ }^{* *} \mathrm{p}<0.01$. Standard errors in parentheses. Time dummies are included but not reported. One-step SGMM estimates. All calculations made in STATA. 
consistent (according to the $\operatorname{AR}(2)$ and Hansen-Sargan tests) ${ }^{10}$. The speed of divergence across Polish regions amounted to about $1.26 \%$ a year $(\beta=-0.0126)^{11}$.

Across the country, it can be seen that regions with a lower initial level of GDP per capita progressed further in closing the technology and innovation gaps but failed in bridging the structural gap. The research results also indicate the existence of a correlation between the progress in closing the structural gap and the dynamics of GDP per capita. Nevertheless, due to statistical insignificance, there is no premise to confirm the relationship between bridging the other categories of development gaps and stimulating the rate of change in GDP per capita.

Table 5. Correlation ${ }^{\star}$ between the development gaps and GDP per capita in Polish regions (2004-2015) (source: own calculations)

\begin{tabular}{|c|c|c|c|c|c|}
\hline$\Delta D G_{1}$ & $\Delta D G_{2}$ & $\Delta D G_{3}$ & $\Delta D G_{4}$ & $\Delta D G_{5}$ & $\Delta D G_{6}$ \\
\hline \multicolumn{6}{|c|}{ GDPpc (2004) } \\
\hline-0.661 & -0.591 & -0.086 & -0.137 & -0.389 & 0.632 \\
\hline \multicolumn{7}{|c|}{ GDPpc growth rate (2004-2015) } \\
\hline-0.366 & -0.215 & 0.419 & 0.356 & 0.042 & 0.909 \\
\hline
\end{tabular}

Note: ${ }^{*}$ correlation is significant at the 0.05 level. Insignificant correlations are reported in italics.

\section{EU structural funds in reducing development gaps}

The results of the correlation analysis (Table 6) do not provide strong premises for making conclusions on the impact of structural funds on eliminating interregional development disparities in Poland. We can only observe that higher intensity in the allocation of EU structural funds per capita contributed to closing the transport accessibility gap $\left(D G_{4}\right)$. A negative correlation was shown between the global value of EU funds and progress in bridging the innovation gap $\left(\Delta D G_{2}\right)$. Such a result, however, should not be used to draw the conclusion that EU funds do not foster innovation, but rather to conclude that they have been allocated mostly to areas that do not create innovation. This is also in line with the results of research conducted by Misiąg et al. (2013) and Gorzelak (2014).

Table 6. Correlations between the volume of EU structural funds and progress in reducing the development gaps in Polish regions (2004-2015) (source: own calculations)

\begin{tabular}{|c|c|c|c|c|c|}
\hline$\Delta D G_{1}$ & $\Delta D G_{2}$ & $\Delta D G_{3}$ & $\Delta D G_{4}$ & $\Delta D G_{5}$ & $\Delta D G_{6}$ \\
\hline \multicolumn{5}{|c|}{ EU structural funds per capita } \\
\hline 0.197 & -0.110 & -0.085 & 0.614 & -0.131 & -0.351 \\
\hline \multicolumn{7}{|c|}{ EU structural funds (total) } \\
\hline-0.358 & -0.648 & 0.104 & 0.083 & -0.408 & 0.375 \\
\hline
\end{tabular}

Note: ${ }^{*}$ Correlation is significant at the 0.05 level. Insignificant correlations are reported in italics.

\footnotetext{
10 The sGMM estimates for the GDP per capita lagged variable lie near the range of 0.706 (LSDV estimate) to 1.01 (OLS estimate). They also indicate a plausible estimate (Roodman, 2009, p. 103).

11 Parameter $\gamma$ is defined as: $\gamma=\frac{1}{T}\left(1-e^{-\beta T}\right)$. The $\beta$-value indicates the rate at which regions approach their steady state and, hence, the speed of convergence (Dańska-Borsiak, 2011).
} 
The estimation results for Equation No. 4 (Table 7) indicate a difference in the impact of the structural funds per capita on closing the respective development gaps. The results of the calculations suggest that:

- a statistically significant and positive impact of EU structural funds on bridging the transport availability gap $\left(D G_{4}\right)$. Estimate No. 13 shows that EU funds help to explain the level of the $D G_{4}$ gap even when controlling for the level of this gap in the previous period. The results are not sensitive to the inclusion of other control variables (Estimate No. 14);

- a statistically significant and positive impact of EU structural funds on bridging the investment gap $\left(D G_{5}\right)$. Although in Estimation No. 17 the EU funds turned out to be statistically insignificant, adding a set of control variables (Estimation No. 18) significantly alters the results. Other things held equal, the progress in closing the investment gap was, on average, accompanied by a higher inflow of EU funds per capita.

Nevertheless, there are also indications that EU funds may have an opposite impact on regional disparities. The allocation of structural funds could lead to the increase in regional disparities in terms of the innovation gap $\left(D G_{2}\right)$. Although Estimation No. 5 suggests that EU funds did not influence the level of the innovation gap, these results are sensitive to the inclusion of other control variables; in Estimation No. 6 EU funds turned out to be statistically significant.

Moreover, the impact of EU funds on changes in the technological gap (Estimations No. 1-2), the human capital gap (Estimations No. 9-10) and the structural gap (Estimations No. 21-22) was not confirmed.

These results are statistically significant and the sGMM estimations seem to be consistent, as indicated by the AR(2), Hansen-Sargan and difference-in-Sargan/Hansen tests. Estimations provide also a robustness check to the choice of instrument - in Estimations No. 1-24 the instruments were collapsed (Rodman, 2009).

Among Polish regions, there are some where the level of resource endowment $\left(X_{1}-X_{6}\right)$ stands out from the rest. In particular, Mazowieckie is characterised by the exceptionally high level of development of $X_{1}, X_{2}, X_{3}, X_{5}$ and $X_{6}$, and Slaskie is characterised by a very high density of expressways and motorways $\left(X_{4}\right)$. These two are leaders among Polish regions (see Table 2). Therefore, one may suspect that the results of previous estimations were driven primarily by the leader regions. As an added robustness check, we have re-estimated Equation No. 4 excluding these regions from the sample (Table 7). The results for the basic equations for all $D G$ categories turned out to be unaffected by such a tweak. The results of the re-estimations suggest a statistically significant and positive impact of EU structural funds on bridging the transport availability gap (Estimations No. 15-16), the investment gap (Estimations No. 19-20) and negative impact on the innovation gap (Estimations No. 7-8). Again, there is a lack of clear evidence to confirm the impact of structural funds on reducing the technological gap (Estimations No. 3-4), the human capital gap (Estimations No. 11-12) and the structural gap (Estimations No. 23-24).

This is not an exceptional situation because research from previous years in different EU countries demonstrates weaker than average impact of European funds on the dynamics of development of less developed regions, including improvement in the labour market (despite 
苂

3

㐫

త్ర

苞

害.

灵

0

$\frac{0}{3}$

$\stackrel{\circ}{+}$

艺

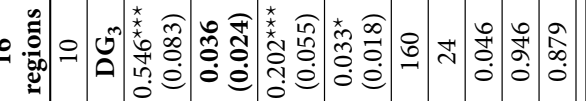

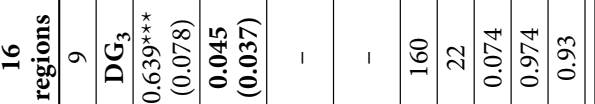

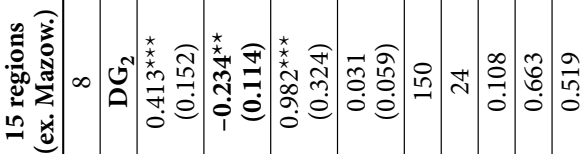
跣

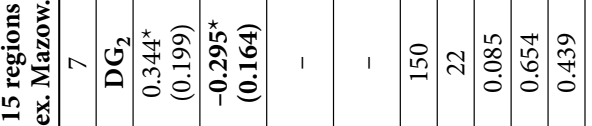

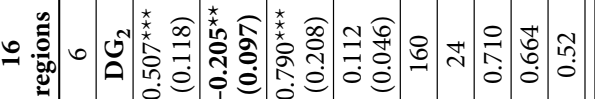

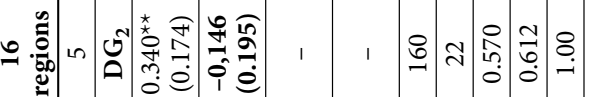

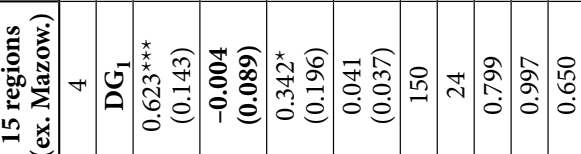
放

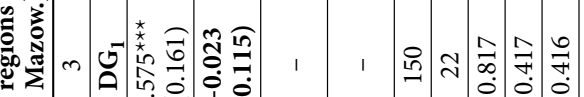

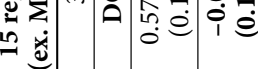

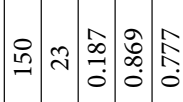
$=0$

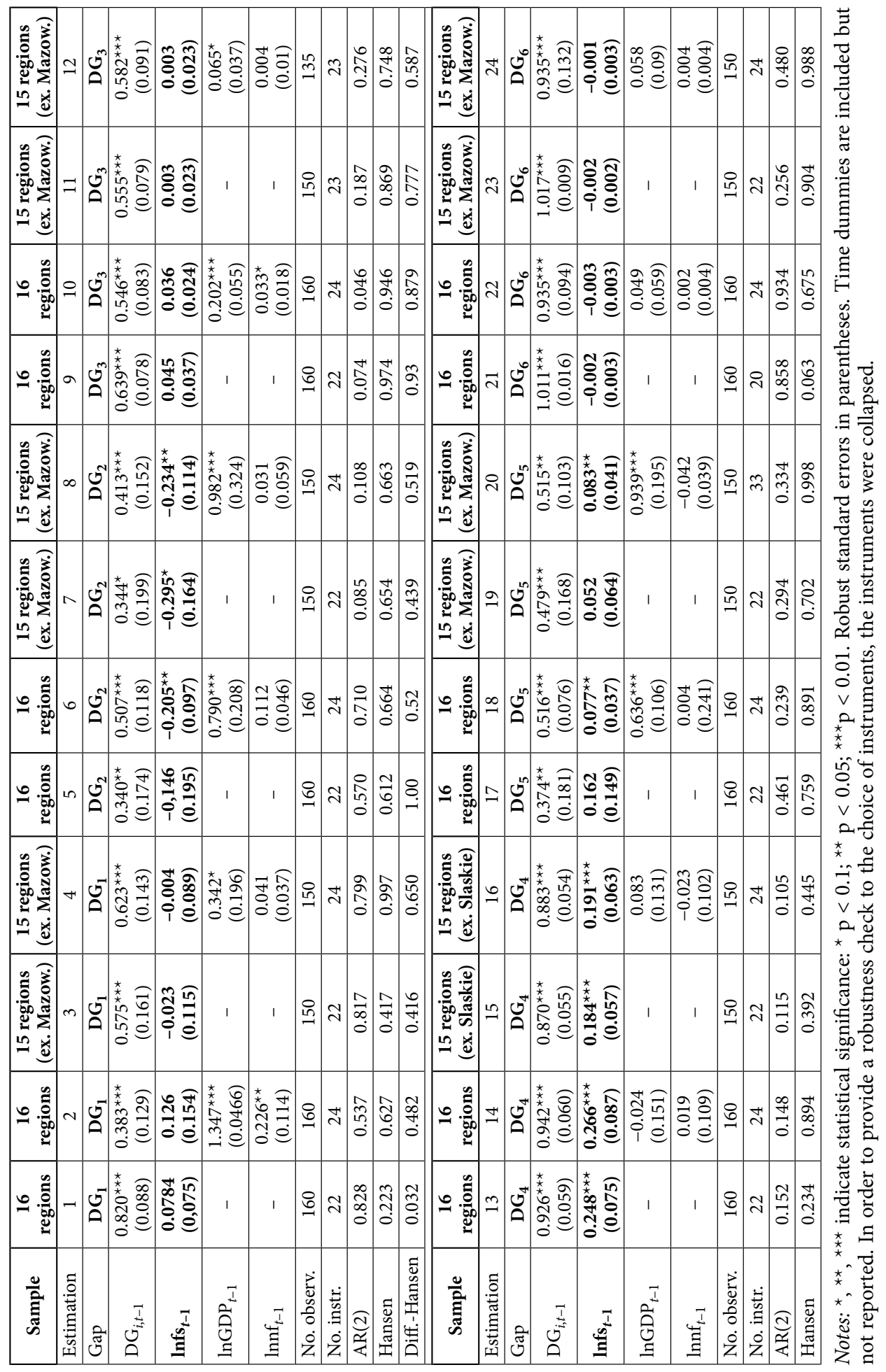


GDP growth per capita) and the competitiveness of the economy. The functioning of at least three "growth clubs" in the EU was also found, each with different dynamics of development (Fagerberg \& Verspagen, 1996; Boldrin \& Canova, 2001; Becker, Egger, \& Von Ehrlich, 2010; Bouayad-Agha, Turpin, \& Védrine, 2013).

The impact of EU funds on development gaps can result e.g. from the specific focus of EU expenditure, which after 2004 in Poland centered on the elimination of the infrastructural gap (road investments). After 2004, nearly all investments in road networks in Poland were based on EU funds. Significant EU resources were allocated to the enterprise sector in the same period (hence their impact on the investment gap, $D G_{5}$ ), though they were still not sufficient to establish technological competitive advantage, which is confirmed by the conclusions of other studies. This is the reason why there is no confirmed impact on the $D G_{1}$ gap or negative impact on the $D G_{2}$ gap. Further, EU funds have not contributed to a change in the human capital and structural gaps. Both education and economic structures are quite firmly fixed, which can be attributed to enduring social and economic processes. Identifying the impact of EU funds on a shift in the human capital and structural gaps may require longer term investigation.

The research presented in this study, as compared to the initiatives undertaken thus far, stands out due to the proposed approach to analysing the impact of structural funds on the processes of regional convergence through the prism of development gaps. In this regard, the presented proposal triggers a discussion on the development of an adequate way to measure the impact of EU funds on bridging development gaps and linking these processes to income convergence. In particular, one of the objectives of these activities is to verify the hypothetical relation between the level of the income convergence of regions (approximation of GDP per capita) and the scale of the reduction of development gaps, partially confirmed in our studies and shown in Figure 2.

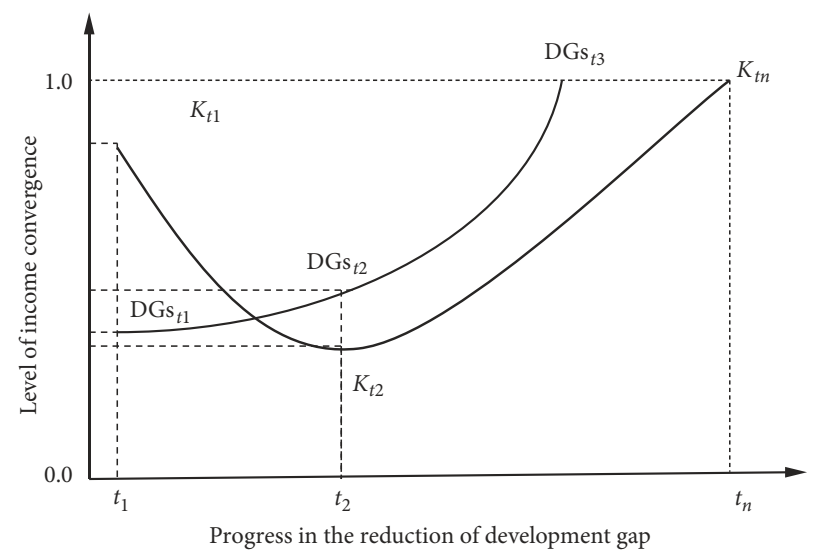

Parameter $K$ determines the level of income convergence for the period $\left[t ; t_{n}\right]$, according to the formula:

$$
K_{t i}=\frac{\mathrm{GDPpc}_{Z i}}{\mathrm{GDPpc}_{K i}}
$$

where: GDP $\mathrm{pc}_{Z i}$ - GDP per capita of the backward region in period $t_{i}$; GDP pc $\mathrm{c}_{K i}$ - average domestic GDP per capita in period $t_{i}$.

Figure 2. The relationship between the level of income convergence and the scale of development gap (source: own study) 
$K=1$ means the total convergence of GDP per capita in a region lagging behind in comparison with the national average. $D G_{i}=1$ denotes that there is no difference in the level of development gaps between a region lagging behind and the national average. The time $(t)$ in which the changes of the analysed values occur is an important dimension of this relationship.

Each gap closes at a different pace. The structural gap showed the highest degree of stability (the highest value of the autoregressive parameter $D G_{i, t-1}$; see Table 7). Moreover, the reduction of this gap alone has shown a stimulating impact on the change of GDP per capita (Table 5). The inertia marking the structural gap may be one of the reasons for the lack of progress in interregional income convergence, despite the bridging of other categories of development gaps.

As shown in Figure 2, when the development gap in a region is high (low value of $D G_{i}$ ), even its reduction (increase in the value of the gap indicator to the level of $D G_{t 2}$ ) does not result in progress in terms of convergence (reduction of the value of the parameter of income convergence from $K_{t 1}$ to $K_{t 2}$ ). This relationship might explain the fact, as shown by numerous authors (Misiąg et al., 2013; Kozak, 2014), that despite allocating substantial public funds (including EU funds) to the reduction of development gaps, there is no progress in income convergence in the regions of Poland. It should be pointed out, however, that the lack of a positive relationship between the support for regional development with external funds and progress in their income convergence does not mean that reducing development gaps is an ineffective tool in supporting regional convergence. Alternatively, it could mean that the time and financial resources allocated for reducing development gaps might be insufficient to reverse the negative trend of income polarisation in regions in Poland. As shown in research conducted in recent years, the positive impact of EU funds on the dynamisation of regional development and the acceleration of the convergence process is linked to the scale of such support. Transfers that are too low (but also too high) do not bring about optimal results (Becker, Egger, \& Von Ehrlich, 2012, 2018; Cerqua \& Pellegrini, 2018).

Income disparities between regions may deepen because:

- more time is needed to bring about significant structural changes that could reverse the current trend (deepening of differences);

- the scale of the reduction in the gap is still so small that it does not allow for trend reversal (for example external investors still do not see positive changes);

- institutional hysteresis takes place (the institutional environment has not kept pace with the changes in the economic and social environments);

- in addition to the gap that is being reduced, there are other gaps, for which public funds are not allocated (or are too small), which slow the pace of positive change.

The verification of the reasons presented above, causing the initial absence of convergence processes in response to the reduction of development gaps - until a certain critical point of change is reached (taking into account the time factor) - requires additional in-depth empirical research. Its implementation is beyond the scope of this study. The theses mentioned above, however, explain at least to some extent the reasons behind the low efficiency of support from EU funds for the processes of regional income convergence in Poland. 
Upon exceeding the "critical point" in terms of reducing development gaps $\left(D G_{i}\right)$, the incentives encouraging regional development begin to have an increased impact. Besides, what is also essential is the "displacement effect"; that is, the fact that some advantageous trends are revealed in "deferred time" As shown in Figure 2, it takes time to reverse a negative trend and "go beyond" the $K_{t 1}$ point in terms of income convergence. If it were not for the reduction in the development gap, the curve illustrating income convergence would drop lower and lower, which would signal increased polarisation. Nowadays, that polarisation factors are very strong (Podkaminer, 2015), as they are associated with globalisation (e.g. the speed and ease of capital flow searching for "a better place" to achieve higher returns, network economy, high labour mobility), even the reversal of the dominant polarisation trend may be considered a success (Mihályi, 2014). Halting polarisation processes and the marginalisation of peripheral areas are the first steps towards initiating the process of convergence.

The results of our research show that in the case of EP regions, the process of reducing development gaps has not gone beyond a "critical point" (in Figure 2, this is the $D G_{i 2}$ level) that would lead to a reversal of the processes of income divergence (in Figure 2, this is the $K_{t 2}$ point).

\section{Conclusions}

On the basis of the conducted study, several conclusions can be formulated:

1. Progress has been made towards reducing development gaps in EP regions in 20042015. This is proven by the reduction in the disparities between EP regions and other regions in Poland, in particular in terms of $\mathrm{R} \& \mathrm{D}$ expenditure, the number of patents, and transport accessibility (the structural gap is an exception as it increased slightly in 2004-2015). It is not possible to identify a single mechanism for the impact of structural funds on different categories of development gaps. Instead, studies point to a variety of impacts. There are indications that structural funds (per capita) could have had positive impact on reducing the transport accessibility and investment gaps, but negative impact on reducing the innovation gap. Furthermore, the results of the calculations are not sufficient to confirm unequivocally the strength and direction of the impact of structural funds on the level of the remaining gaps under consideration. Under these circumstances, it cannot be clearly stated that hypothesis No. 1 is positively verified.

2. Progress towards closing the development gaps is not large enough to reduce significantly the GDP per capita gap between EP regions and more developed regions in the country, which is a confirmation of hypothesis No. 2. The reason might be that EU funds have very limited impact on boosting structural changes in the economies of EP regions (structural gap $D G_{6}$ ), and reduction in the development gap can be of key importance for income convergence. The situation could be improved in this respect through the introduction of changes in the structure of using EU funds. Changes should involve higher expenditure on entrepreneurship and the creation of new jobs in the eastern regions of Poland for 2014-2020. One cannot exclude the possibility that our studies did not manage to identify a positive impact of the elimination of develop- 
ment gaps on convergence due to the period between the disbursement of EU funds and our studies on its effects being too short. Effects can be observed in the improved level of education, the condition of infrastructure and the increase in investment expenditure, but more time is necessary to observe those effects that can be measured with GDP increase. Future studies could include the identification of new development gaps revealed following economic and social changes in Poland (for example, with regard to institutional conditions, social capital, foreign investors' activity and spatial interactions between regions).

3. EU programmes implemented in 2014-2020, in particular the Eastern Poland OP, specifically dedicated to EP regions, should contribute to changes in the structure of their economy to a greater extent than has been the case so far. As our research shows, the structural gap did not diminish by 2015 and the interregional disparities in this respect were also aggravated. Without significant progress materialising in the establishment and development of competitive economic entities, there will be no convergence process. Additionally, further reduction of the remaining development gaps will not bring about any major economic effects either, in a situation where expenditures on $\mathrm{R} \& \mathrm{D}$, improvement in the quality of human capital or the construction of transport networks do not stimulate the development of companies that are characterised by, among other things, the ability to adapt quickly and flexibly to changing economic conditions at the micro and macro scales.

The research presented above indicates the need for additional in-depth empirical research to verify the relationship shown in Figure 2 (as a longer period of time is required for a comprehensive evaluation of convergence processes in response to the reduction of development gaps). Further studies could investigate: a) additional reasons causing the initial absence of convergence in response to the reduction of development gaps (i.e. the role of institutions); b) the adequacy of the methods used (i.e. spatial econometric methods) to assess the relationship between the impact of EU funds on the development gaps and income convergence. Nevertheless, reliable data - collected from the regional system and divided in individual intervention goals - are needed to assess the effects of the EU Cohesion Policy. It should be noted that the full effects of structural expenditure will only become apparent once a few years have passed from the concluded investments.

\section{Acknowledgements}

The authors are grateful to two anonymous reviewers for the thoughtful comments that help to improve the quality of the manuscript.

\section{Funding}

This work has been supported by the funds of the Ministry of Science and Higher Education granted to the Faculty of Economics, University of Rzeszow, Poland, within the subsidy for maintaining research potential. 


\section{Author contributions}

The authors contributed equally and are listed in alphabetical order. Adam Czudec, Ryszard Kata and Małgorzata Wosiek conceived the study and were responsible for the design and development of the data analysis. Ryszard Kata and Małgorzata Wosiek were responsible for data collection and analysis. Adam Czudec, Ryszard Kata and Małgorzata Wosiek were responsible for data interpretation. Adam Czudec and Ryszard Kata wrote the first draft of the article.

\section{Disclosure statement}

We hereby declare that: a) the article is new and has not been published anywhere; b) author(s) indicated in the text is the actual author of the text; c) article is free from legal defects, and the rights of third parties are not infringed.

\section{References}

Alecke, B., Mitze, T., \& Untiedt, G. (2013). Growth effects of regional policy in Germany: results from a spatially augmented multiplicative interaction model. Annals of Regional Science, 50(2), 535-554. https://doi.org/10.1007/s00168-012-0503-7

Badinger, H., Müller, W. G., \& Tondl, G. (2004). Regional convergence in the European Union, 1985-1999: a spatial dynamic panel analysis. Regional Studies, 38(3), 241-253. https://doi.org/10.1080/003434042000211105

Bal-Domańska, B. (2014). Próba identyfikacji większych skupisk regionalnych oraz ich konwergencja. Prace Naukowe Uniwersytetu Ekonomicznego we Wrocławiu, 327, 285-293.

Barro, R. J., \& Sala-i-Martin, X. (1992). Convergence. Journal of Political Economy, 100(2), 223-251. https://doi.org/110.1086/261816

Barro, R. J., \& Sala-i-Martin, X. (1991). Convergence across States and Regions. Brookings Papers on Economic Activity, 22(1), 107-182. https://doi.org/10.2307/2534639

Becker, S. O., Egger, P. H., \& Von Ehrlich, M. (2010). Going NUTS: The effect of EU structural funds on regional performance. Journal of Public Economics, 94, 578-590. https://doi.org/10.1016/j.jpubeco.2010.06.006

Becker, S. O., Egger, P. H., \& Von Ehrlich, M. (2012). Too much of a good thing? On the growth effects of the EU's regional policy. European Economic Review, 56(4), 648-668. https://doi.org/10.1016/j.euroecorev.2012.03.001

Becker, S. O., Egger, P. H., \& Von Ehrlich, M. (2018). Effects of EU regional policy: 1989-2013. Regional Science and Urban Economics, 69, 143-152. https://doi.org/10.1016/j.regsciurbeco.2017.12.001

Bełz, G., Malinowski, P., \& Olejczyk, Z. (2013). Centrum Nowych Technologii w strategii rozwoju przedsiębiorstw branży komunalnej. Prace Naukowe Uniwersytetu Ekonomicznego we Wrocławiu, 299, 9-23.

Boldrin, M., \& Canova, F. (2001). Inequality and convergence in Europe's regions: reconsidering European regional policies. Economic Policy, 16(32), 206-253. https://doi.org/10.1111/1468-0327.00074

Borowiec, J. (2015). Konwergencja regionalna w Unii Europejskiej. Prace Naukowe Uniwersytetu Ekonomicznego we Wrocławiu, 380, 15-25. https://doi.org/10.15611/pn.2015.380.01

Bouayad-Agha, S., Turpin, N., \& Védrine, L. (2013). Fostering the development of European regions: A spatial dynamic panel data analysis of the impact of cohesion policy. Regional Studies, 47(9), 1573-1593. https://doi.org/10.1080/00343404.2011.628930 
Camagni, R. (1995). The concept of innovative milieu and its relevance for public policies in European lagging regions. Papers for Regional Science Association, 4, 55-67. https://doi.org/10.1111/j.1435-5597.1995.tb00644.x

Cerqua, A., \& Pellegrini, G. (2018). Are we spending too much to grow? The case of Structural Funds. Journal of Regional Science, 58(3), 535-563. https://doi.org/10.1111/jors.12365

Chrzanowski, M. (2015). Polityka regionalna a system finansów publicznych. Wplyw wydatków strukturalnych na tempo konwergencji polskich regionów. Warsaw: Oficyna Wydawnicza SGH.

Churski, P. (2004). Rozwój regionalny w warunkach transformacji gospodarczej i integracji europejskiej. In S. Ciok \& D. Ilnicki (Ed.), Przekształcenia regionalnych struktur funkcjonalno-przestrzennych. Regionalny wymiar integracji europejskiej (t. 8/1, pp. 31-46). Wrocław: Uniwersytet Wrocławski.

Churski, P. (2008). Structural Funds of the European Union in Poland - experience of the first period of membership. European Planning Studies, 16(4), 579-607. https://doi.org/10.1080/09654310801983506

Čihák, M., \& Fonteyne, W. (2009). Five years after: European Union membership and macro-financial stability in the New Member States (IMF Working Paper No. WP/09/68). Washington, DC: International Monetary Fund.

Czudec, A. (Ed.). (2009). Czynniki kształtujące spójność ekonomiczną i społeczną regionu. In Możliwości i bariery rozwoju regionu (pp. 13-30). Rzeszów: Wydawnictwo Uniwersytetu Rzeszowskiego.

Dańska-Borsiak, B. (2011). Dynamiczne modele panelowe w badaniach ekonomicznych. Łódź: Wydawnictwo Uniwersytetu Łódzkiego.

Del Bo, Ch., Florio, M., \& Manzi, G. (2010). Regional infrastructure and convergence: Growth implications in a Spatial Framework. Transition Studies Review, 17, 475-493.

https://doi.org/10.1007/s11300-010-0160-4

Ederveen, S., De Groot, H. L., \& Nahuis, R. (2006). Fertile soil for structural funds? A panel data analysis of the conditional effectiveness of European cohesion policy. Kyklos, 59(1), 17-42.

https://doi.org/10.1111/j.1467-6435.2006.00318.x

Ekspertyzy do Strategii Rozwoju Polski Wschodniej do 2020 roku. (2007). Warsaw: Ministry of Regional Development.

European Funds Portal. (n.d.). Development of Eastern Poland. Retrieved from http://www.polskawschodnia.2007-2013.gov.pl/english/Strony/Introduction.aspx

Fagerberg, J., \& Verspagen, B. (1996). Heading for divergence? Regional growth in Europe reconsidered. JCMS: Journal of Common Market Studies, 34(3), 431-448.

https://doi.org/10.1111/j.1468-5965.1996.tb00580.x

Firgo, M., \& Huber, P. (2014). Convergence as a heterogeneous process: what can be learnt about convergence in EMU from regional experiences? Empirica, 41, 129-151.

https://doi.org/10.1007/s10663-013-9242-y

Fischer, M. M., \& LeSage, J. P. (2015). Bayesian space - time approach to identifying and interpreting regional convergence clubs in Europe. Papers in Regional Science, 94(4), 677-702.

https://doi.org/10.1111/pirs.12104

Gorynia, M., Nowak, J., \& Wolniak, R. (2007). Poland and Its Investment Development Path. Eastern European Economics, 45(2), 52-74. https://doi.org/10.2753/EEE0012-8775450203

Gorzelak, G. (2014). Wykorzystanie środków Unii Europejskiej dla rozwoju kraju - wstępne analizy. Studia Regionalne i Lokalne, 3(57), 5-25.

Grabicz, M. (2012). Problemy rozwoju i zacofania ekonomicznego. Warsaw: Wolters Kluwer.

Hurju, M. C. (2015). Convergence of regional development in the European Union. The USV Annals of Economic and Public Administration, 15, 71-80.

Jabłoński, Ł. (2012). Kapitał ludzki a konwergencja gospodarcza. Warsaw: Wydawnictwo C.H. Beck.

Kozak, M. W. (2014). 10 lat polityki spójności w Polsce. Studia Regionalne i Lokalne, 4(58), 25-50. 
Krugman, P. (1998). Development geography economics theory. Cambridge-London: MIT Press.

Kubielas, S. (2009). Innowacje i luka technologiczna w gospodarce globalnej opartej na wiedzy: strukturalne i makroekonomiczne uwarunkowania. Warsaw: Warsaw University.

Lewandowska, A. (2016) EU Funds. The challenge for innovation and regional disparity in Poland. Barometr Regionalny. Analizy i Prognozy, 14(3), 33-40.

Lewandowska, A., Stopa, M., \& Humenny, G. (2015). The European Union Structural Funds and regional development. The perspective of small and medium enterprises in Eastern Poland. European Planning Studies, 23(4), 785-797. https://doi.org/10.1080/09654313.2014.970132

Mankiw, N. G., Romer, D., \& Weil, D. N. (1992). A contribution to the empirics of economic growth. Quarterly Journal of Economics, 107(2), 407-437. https://doi.org/10.2307/2118477

Mihályi, P. (2014). Post-Socialist transition in a 25-year perspective. Acta Oeconomica, 64, 1-24. https://doi.org/10.1556/AOecon.64.2014.S1.1

Mikulić, D., Lovrincević, Ż., \& Galić-Nagyszombaty, A. (2013). Regional convergence in the European Union, new member states and Croatia. South East European Journal of Economics and Business, 8(1), 7-19. https://doi.org/10.2478/jeb-2013-0001

Misiąg, J., Misiąg, W., \& Tomalak, M. (2013). Ocena efektywności wykorzystania pomocy finansowej Unii Europejskiej jako instrumentu polityki spójności społeczno-gospodarczej oraz poprawy warunków życia. Rzeszów: Wydawnictwo WSIiZ.

Moisescu, E. R. (2015). Regional convergence. Case of Romania. Theoretical and Applied Economics, XXII/2(603), 183-188.

Monfort, P., \& Nicolini, R. (2000). Regional convergence and international integration. Journal of Urban Economics, 48, 286-306. https://doi.org/10.1006/juec.1999.2167

Mora, T. (2008). Factors conditioning the formation of European regional convergence clubs. Annals of Regional Science, 42, 911-927. https://doi.org/10.1007/s00168-007-0191-x

Mucha-Leszko, B. (2013). Możliwości zmniejszania luki rozwojowej Polski w Unii Europejskiej i wobec krajów o największym potencjale gospodarczym w perspektywie 2040 roku. Finanse, Rynki Finansowe, Ubezpieczenia, 57, 429-442.

Nazarczuk, J. M. (2013). Potencjał rozwojowy a atrakcyjność inwestycyjna województw i podregionów Polski. Olsztyn: UWM.

Neumann, U., Budde, R., \& Ehlert, C. (2014). Economic growth in European city regions. A new turn peripheral regions in CEE member states after the EU enlargements of 2004-2007? Eastern European Economics, 52(1), 79-108. https://doi.org/10.2753/EEE0012-8775520104

Niebuhr, A., \& Schlitte, F. (2009). EU enlargement and convergence: Does market access matter? Eastern European Economics, 47(3), 28-56. https://doi.org/10.2753/EEE0012-8775470302

Ozgen, C., Nijkamp, P., \& Poot, J. (2010). The effect of migration on income growth and convergence: Meta-analytic evidence. Regional Science, 89, 537-553. https://doi.org/10.1111/j.1435-5957.2010.00313.x

Pardo Garcia, I. (2005). Growth, convergence, and social cohesion in the European Union. International Advances in Economic Research, 11, 459-467. https://doi.org/10.1007/s11294-005-6613-6

Piętak, Ł. (2015). Convergence across Polish regions 2005-2011. Comparative Economic Research, 18(2), 99-118. https://doi.org/10.1515/cer-2015-0014

Podkaminer, L. (2015). Central and Eastern Europe: Trapped in integration? Acta Oeconomica, 65, 83106. https://doi.org/10.1556/032.65.2015.S1.6

Próchniak, M. (2009). Czynniki wzrostu gospodarczego - przegląd wyników badań empirycznych. In R. Rapacki (Ed.), Wzrost gospodarczy w krajach transformacji. Konwergencja czy dywergencja? (pp. 32-73). Warsaw: PWE. 
Próchniak, M., \& Witkowski, B. (2013). Real $\beta$-convergence of transition countries. Eastern European Economics, 51(3), 6-26. https://doi.org/10.2753/EEE0012-8775510301

Program Polska Wschodnia 2014-2020. (2015). Warsaw: Ministry of Infrastructure and Development.

Puigcerver-Penalver, M. C. (2007). The impact of structural funds policy on European regions growth. A theoretical and empirical approach. The European Journal of Comparative Economics, 4(2), 179-208.

Ramajo, J., Marquez, M. A., Hewings, G. J., \& Salinas, M. M. (2008). Spatial heterogeneity and interregional spillovers in the European Union: Do cohesion policies encourage convergence across regions? European Economic Review, 52(3), 551-567. https://doi.org/10.1016/j.euroecorev.2007.05.006

Recher, V., \& Kurnoga, N. (2017). European integration perspectives: From cohesion to divergence? Acta Oeconomica, 67(2), 195-214. https://doi.org/10.1556/032.2017.67.2.3

Rodríguez-Pose, A., \& Garcilazo, E. (2015). Quality of government and the returns of investment: Examining the impact of cohesion expenditure in European regions. Regional Studies, 49(8), 12741290. https://doi.org/10.1080/00343404.2015.1007933

Roodman, D. (2009). How to do xtabond2: an introduction to difference and system GMM in Stata. Stata Journal, 9(1), 86-136. https://doi.org/10.1177/1536867X0900900106

Salvati, L. (2014). Convergence in environmental quality and land resource degradation: towards a newly emerging paradigm? Current Politics Economics of Europe, 25(3-4), 431-440.

Schadler, S., Mody, A., Abiad, A., \& Leigh, D. (2006). Growth in the central and Eastern European countries of the European Union. (Occasional Paper No. 252). Washington, DC: International Monetary Fund.

Spellerberg, A., Huschka, D., \& Habich, R. (2007). Quality of life in rural areas: processes of divergence and convergence. Social Indicators Research, 83, 283-307. https://doi.org/10.1007/s11205-006-9057-3

Szlachta, J. (2016). Polityka rozwojowa w kontekście polityki spójności - przypadek Polski w latach 2014-2020. Prace i Materialy Instytutu Rozwoju Gospodarczego SGH, 98, 131-150.

Thiessen, F., van Oort, F., Diodato, D. D., \& Ruijs, A. (2013). Regional competitiveness and smart specialization in Europe. Northampton, MA: Edward Elgar, Cheltenham, UK.

Tusińska, M. (2012). Rozwój społeczno-ekonomiczny krajów peryferyjnych Unii Europejskiej. Economics and Law, IX(2), 47-63. https://doi.org/10.12775/EiP.2012.016 